\title{
THE RELATIONSHIP BETWEEN ONLINE LEARNING AND STUDENT'S PERFORMANCE IN THE RURAL AREAS IN MALAYSIA - THE MEDIATING ROLE OF PARENT'S SUPPORT
}

\author{
Kumaran Kanapathipillai ${ }^{1 i}$, \\ Subaneeswasri Narayanan ${ }^{2}$ \\ ${ }^{1}$ Faculty of Business and Technology, \\ UNITAR International University, \\ Tierra Crest, Jalan SS6/3, \\ Kelana Jaya, 47301 Petaling Jaya, \\ Selangor, Malaysia \\ ${ }^{2}$ Academician, \\ Independent Researcher \& Education Consultant, \\ Malaysia
}

\begin{abstract}
:
This study was undertaken during the Covid-19 pandemic lockdown to scrutinise the mediating role of parental support on the relationship between online learning and student's academic performance. To realise the objectives, the researchers used the quantitative approach to explore this mediating effect. The population of this study was 7.4 million families who are living in the rural areas in Malaysia. Using the simple random sampling method, 650 parents in rural areas were chosen as the participants in this research. For data collection, closed-ended questionnaires were used by the researchers. Out of the 650 questionnaires, 437 were collected, but only 426 could be used as the respondents did not fully complete the rest. The results of this research illuminated that parent's intervention and support are statistically and significantly necessary during their children's online learning sessions to enhance their children's academic performance during the Covid-19 pandemic. This research can guide academics in public and private education sectors, parents, and the Ministry of Education to focus and upgrade the online learning and teaching methodologies rather than just depending on conventional teaching and learning methodologies. Online learning could be beneficial whenever a catastrophic incident occurs that may disrupt children's education; as such, it would be wise to encourage parents to be always ready for this new way of learning in the new milieu.
\end{abstract}

Keywords: online learning, parent's support, academic performance, students, rural area

i Correspondence: email kumar.erapintar@gmail.com 


\section{Introduction}

The unforgiving silent enemy (Covid-19) virus has ravaged 4.5 million lives as of September 2021 worldwide, and the numbers are growing (WHO, 2021). A staggering amount of 310,074 children in Malaysia have been infected with the SARS-CoV-2 from the beginning of the pandemic till September 2021. A total of forty-seven children under the age of eighteen have lost their lives to this merciless silent killer (Ishak, 2021). With the onslaught of this silent killer rampaging the nation, The Ministry of Education has closed the schools since November 2020. During this closure, teaching and learning shifted from the conventional "brick and mortar" or face-to-face mode to e-learning or online mode (Smith et al., 2016). Moreover, (UNESCO, 2020) has encouraged online learning so that students learning process is not disrupted. Shehzadi (2020) has highlighted that many educational institutions and schools have opted for online learning to fight the SARS-CoV-2 virus as this is the best solution to break the chain of infection.

The online mode of teaching and learning was the best solution to maintain physical distancing and curb the spread and casualties of Covid-19. However, one question remains unanswered whether online learning could escalate student's performance similar to physical classroom interaction. Additionally, students in the suburban area may be affected by the closure of schools. The suburban communities lack internet access and digital devices, as mentioned by (Dube, 2020). Therefore, the suburban student's performance may decline as young learners compared to mature learners (Cheesman et al., 2006). Parents' intervention is vital to ensure that the students in these disadvantaged communities maintain their performance, as elucidated by (Wang et al., 2020). Nevertheless, parents working from home may also face a dilemma when their children need help during the online session (Bhamani, et al., 2020). Therefore, this research aimed to investigate if parent's intervention through support was significant during online learning to enhance students' academic performance in the suburban areas in Malaysia.

\subsection{Research Problem Statement}

The SARS-CoV-2 pandemic has severely caused an impact on both educators, learners, and families. With the closure of schools for an extended period, educators and learners have missed physical interaction, which is vital for superior learning. However, to ensure students do not miss their lessons and continue to perform, educators have turned to elearning or online sessions (Chang \& Yano, 2020). As for parents who are also working from home, supporting and guiding their children during the online learning sessions were also crucial so that they do not fall back on their educational pursuits (Daniela, 2021). Parents were needed to support their young children. As such, the parents had to balance their work and their children's education (Wang et al., 2020; Bhamani, et al., 2020; Waters et al., 2014). Additionally, parents who are front liners may not be able to support their children who are engaged in online learning at home. Therefore, the performance 
of these students may decline (Daniela, 2021). Front liner parents faced a formidable challenge to support their children in their online learning and have decided that they should defer their education to next year as they feel that online classes may not be effective (Daniela, 2021; Pokhrel \& Chhetri, 2021).

\subsection{Research Objectives}

R01: To examine if there is a significant relationship between online learning and parent's support.

RO2: To scrutinise if there is a significant relationship between parent's support and student's academic performance.

RO3: To study if there is a significant relationship between online learning and student's academic performance.

RO4: To analyse if parent's support mediates the relationship between online learning and student's academic performance.

\subsection{Research Questions}

RQ1: Is there is a significant relationship between online learning and parent's support. RQ2: Is there is a significant relationship between parent's support and student's academic performance.

RQ3: Is there is a significant relationship between online learning and student's academic performance.

RQ4: Does parent's support mediate the relationship between online learning and student's academic performance.

\section{Literature Review and Hypothesis Development}

The following sub-sections focuses on the literature and hypothesis developed with regards to online learning, parent's support, and student's academic performance.

\subsection{Relationship Between Online Learning and Parent's Support}

Before the closure of schools due to the Covid-19 pandemic, conventional teaching and learning were the most preferred method. Online teaching and learning were encouraged when the schools were closed to prevent the SARS-CoV-2 virus from spreading. Parents' roles to ensure student's learning experience was not tarnished in any way was vital immaterial whether it was conventional face-to-face mode or online mode (Amber et al., 2020; Fontanesi et al., 2020; Waters et al., 2014). During the online sessions, parent's guidance and support were crucial to ensure the student's learning process was as smooth as elucidated by (Ribeiro et al., 2021; Tran et al., 2020; Boonk et al., 2018). Besides, scholars (Daniela, 2021; Abuhammad, 2020; Dong et al., 2020; Bhamani et al., 2020; Garbe et al., 2020; Ahn et al., 2013) have indicated that young learners may not be able to use the online platforms such as Microsoft Teams (Ilag, 2018), Google Classroom (Ventayen et al., 2018). Additionally, students may accidentally assess websites that are not suitable 
for them or not educational (Bruni et al., 2015; Byeon \& Hong, 2015). Therefore, parents' support for young learners is vital to ensure that the learning process occurs without any glitches (Mohring et al., 2020; Antipkina \& Ludlow, 2020; Gugiu et al., 2019; HooverDempsey et al., 2005; Hoover-Dempsey \& Sandler, 1997). Furthermore, (Amber et al., 2020; Bozkurt, 2020) in their research found that parents need to inspire and guide the student during the online learning sessions so that students get the most out of the online learning mode.

Moreover, (Bozkurt, 2020; Mohring et al., 2020) have discovered that during the online learning sessions, parents lead the students so that the learning process will be constructive and the student's educational goals will be achieved. Additionally, (Wang et al., 2020; Wilder, 2014) indicated that a bond between the parents and the students would also be formed during the online learning process. Besides, (Mohring et al., 2020; Hurley et al., 2017; Waters et al., 2014) clarify that parents act as ancillary teachers during the online sessions would increase the clarity of the lessons. Students tend to become independent learners during the online learning sessions, which might cause adverse effects to the online educators. With parent's support, students will be able to follow the online syllabus set by the teachers so that students become independent but within the context of the online syllabus (Dong et al., 2020; Kong, 2020).

Additionally, younger students may not be able to follow the schedules of the online learning sessions. Therefore, based on research conducted by (Kong, 2020; Mohring et al., 2020; Wilder, 2014), parent intervention is needed to keep the students updated so that the students do not miss the online sessions. Parents must set up a conducive learning environment (Sanders \& Sheldon, 2009; Cai, 2003). Parents support online learners by allocating a suitable home space, ensuring that the student's learning is continuously monitored. Contrarily, a study conducted by (Yi \& Lee, 2021; Dong et al., 2020) uncovered that parents had numerous problems and challenges during their children's online learning sessions. Additionally, the parents were not well versed with the online platforms and were not ready to accept online learning as a good learning approach.

From the literature above, it was evident that parents will have a significant direct impact on the student's online learning. Therefore, parents must balance being a member of the family and an educator during the online learning process. Based on this theoretical literature, the following hypothesis is devised:

H1: There is a significant relationship between online learning and parent's support.

\subsection{Relationship Between Parent's Support and Student's Academic Performance}

Parental support is any form of engagement between the students and the parent that can hypothetically be envisaged to enhance the student's performance. In other words, parental support is activities that help a student attain or outshine in academic performance. According to (Ribeiro et al., 2021; Epstein, 1994), parental support involves 
parents' involvement with their children related to children's learning process at home and school.

Several research scholars (Lara \& Saracostti, 2019; Amponsah et al., 2018; Masa, 2017; Otani, 2017; Porumbu \& Necsoi, 2013; Valerie, 2011; Lindsay \& Davis, 2009; Harris \& Goodall, 2008; Desforges \& Abouchaar, 2003; Jeynes, 2007; Velez \& Jones, 1997; Epstein \& Sander, 2000; Bowen, 1999; Gould, 1999) have demonstrated that parent support in student's learning is significantly associated with high performance. Furthermore, these researches indicated that the more the parents supported their children, the more positive is the performance effects. These researchers have also proven that the performance is heightened for all types of parent's support in the student's online learning immaterial of the children's ages.

The most effective forms of parent support are when the parents participate directly with the student during the online learning sessions at home (Lara \& Saracostti, 2019; Amponsah et al., 2018). When parents participate in activities such as providing guidance on homework tasks, reading with the student, and instructing students utilizing the study materials provided by the teachers amplifies performance according to (Amponsah et al., 2018; Otani, 2017; Guolaug, 2010; Sui-Chu \& Willms, 1996).

Additionally, researchers (Porumbu \& Necsoi, 2013; Valerie, 2011; Friedel et al., 2010) have discovered that when parents are more proactive than passive, the students tend to show better performance in their studies. Therefore, when parents react enthusiastically to teachers' messages regarding their children's learning and continuously communicate with the teacher, more excellent performance ensues compared to parents who leave their children's learning process to the teachers (Nyarko, 2011; Guolaug, 2010).

Furthermore, when parent actively supports their children at home, this creates a bond between the parent and the children, leading to the more excellent performance of the children's learning (Sheldon, 2009; Richardson, 2009; Sanders, 2009). Moreover, when parents participate in the student's online learning process, they will gain greater assurance and confidence that they will always get their parent's support and guidance, just like when parents get involved in traditional school activities such as field trips or classroom activities (Mau, 1997). This will increase their performance.

According to research conducted by (Gestwicki, 1996) when parents participate and support their children's learning in the early years performance of the children will increase significantly. This can be supported by (Liu et al., 2020; Langevine, 2020), who elucidated that parental support at an early age increases student's performance and promotes emotional development. Therefore, parent's support in student's early childhood education will prove to be effective later on in their educational endeavour.

Based on previous research and scholars, it was noted that parent's support is significant for student's performance. The literature above has indicated that parents provide support to their children in various ways, but no matter how, the parent's support will heighten the student's performance in their studies. It was quite a reverse in a study conducted by (Yi \& Lee, 2021; Dong et al., 2020), who found that parents were 
undergoing various problems, and the children's academic performance decreased tremendously. Therefore, a gap exists in the literature with regards to parental support and student's academic performance. Thus, based on this theoretical literature, the following hypothesis is developed:

H2: There is a significant relationship between parent's support and student's academic performance.

\subsection{Relationship Between Online Learning and Student's Academic Performance}

During the Covid-19 pandemic lockdown, online learning and teaching have intensified (Bayrak et al., 2020; Shehzadi, 2020). Students and teachers were more involved in learning and teaching using online methods where the learning process can take place at home at a lower cost (Bowen, 2013; Garbett, 2011) and by maintaining physical distance (Green, 2010).

Additionally, scholars (Zameni et al., 2011) elucidated that in a world plagued by the SARS-CoV-2 virus, online learning has improved student's academic performance in various academic disciplines similar to traditional face-to-face learning methods (Navarro \& Shoemaker, 2000). To further prove this (Pei \& Wu, 2019; Means et al., 2010) conducted research verifying that students who used the online learning mode performed reasonably better than students who learned through the conventional classroom method. A more recent study conducted by (Gopal et al., 2021; Loton et al., 2020; Fatoni et al., 2020) has established that online learning during the Covid-19 pandemic has increased student's academic performance compared to when classes were conducted in school. Moreover, (Darius et al., 2021; Lockman \& Schirmer, 2020; Najafi, 2012; Riffell \& Sibley, 2005) has affirmed that online learning has heightened student's academic performance through the use of various online platforms and internet facilities. Through internet learning, students experience a new way of interacting with their teachers, which has stimulated interest and motivated students to gain knowledge, leading to amplified academic performance based on the findings (Mahdinejad \& Amoii, 2011).

Online learning and teaching methods during the Covid-19 lockdown have allowed both teachers and students to experience desktop computers, laptops, iPads, smartphones, social media, and various multimedia devices to realise their learning and teaching quicker. According to (Zameni \& Kardan, 2012), the utilisation of online technologies has changed the roles of teachers and the students whereby it has led the students to more excellent academic performance. On the other hand, (Yi \& Lee, 2021) have uncovered that the student's academic performance diminished during the online learning session. Their study revealed that most students were unable to complete their homework independently and lost their interest in learning, resulting in poor academic performance. As such, there exist a gap in the literature that needs addressing. Thus, based on this theoretical literature, the following hypothesis is developed:

H3: There is a significant relationship between online learning and student's academic performance. 


\subsection{The Mediating Role of Parent's Support Between Online Learning and Student's Academic Performance}

The involvement of parents in the student's online learning process at home is termed as parental support in this study (Jeynes, 2005). Additionally, (Gálvez et al., 2016; Wang \& Sheikh_Khalil, 2014; Spera, 2005) exerted that parents who participate in their children's learning activities will result in their children's success compared to parents who do not take the initiative to support their children when online learning session was initiated during the covid-19 pandemic. To support this (Lorenzo et al., 2017; Bradley \& Corwyn, 2002) affirmed that parent's support during online learning at home strengthens the parent-children relationship, which then helps to elevate the children's educational performance.

Based on (Evans et al., 2000), parents can support children's learning process through active involvement and manage the children's learning in the home. This is true for students who are learning online at home during the Covid-19 pandemic lockdown. Parents should participate in cognitively invigorating tasks such as reading together and observing children's online learning period (Finn, 1998). According to (Seginer, 2006) parent's effective management during online learning sessions at home can enhance children's motivation to learn and elevate their educational performance.

Parents who have children in the lower primary between the ages of six to twelve should provide more support than older children during the online learning sessions. The lower primary students will only have the ability to think grounded on the facts that they notice and will have problems when they confront probabilistic and nonfigurative things.

According to (Simatwa, 2010) children in the lower primary are at the level of Concrete Operations as stated in Piaget's Theory of Cognitive Development. These early age students require detailed clarifications about the online lessons conducted at home. Therefore, parent's support is highly crucial for lower primary students who are learning online. Through the parent's continuous support, the student will become more independent in online learning at home and eventually achieve better performance. Based on (Sooter, 2013) the guidance and support provided by parents during the learning process will ultimately create students who are independent and mature in their actions. Conversely, a study conducted in China by (Cui et al., 2021) indicated that online learning caused stress on the parents and reduced the students' academic performance. Therefore, a gap exists regarding the intervening role of parents during their children's online sessions during the Covid-19 pandemic lockdown period. Thus, based on this theoretical literature, the following hypothesis is developed:

H4: Parent's support mediates the relationship between online learning and student's academic performance.

\subsection{Proposed Conceptual Model}

The purpose of this research is to scrutinize the mediating effect of parent's support on the relationship between online learning and student's academic performance in the 
suburban areas in Malaysia. Figure 1 shows the proposed conceptual model developed to illuminate the relationship between variables of this research.

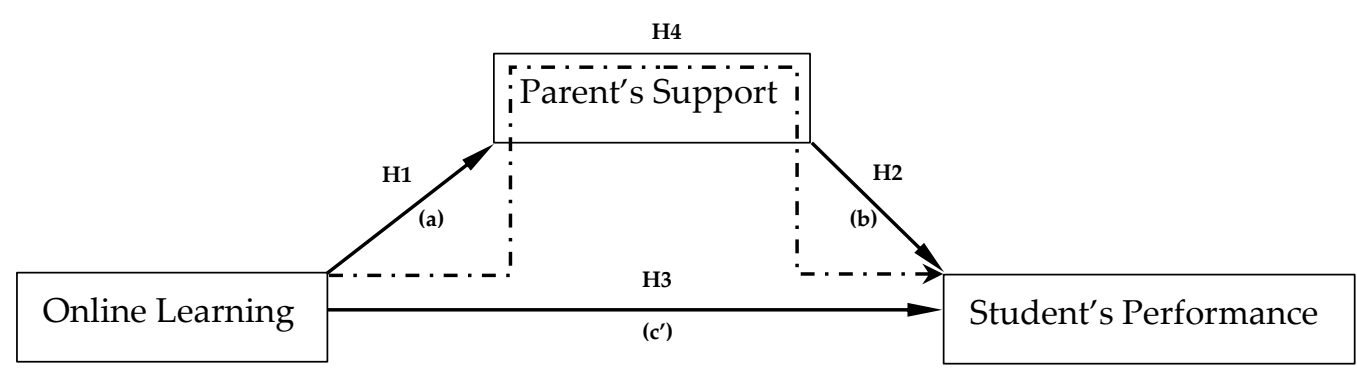

Figure 1: Proposed Conceptual Model

\section{Methodology}

This study scrutinises the relationship between online learning and student's performance with parent's support as the mediating factor. A total of 460 selfadministered survey questionnaires were distributed among parents in the suburban areas in Malaysia. The questionnaires utilised Likert's 5-points scale varying from "Strongly disagree (1)" to "Strongly agree (5)". The survey instrument is comprised of four sections. The first section intended to obtain data about the respondents' demographic profile, the second section generated data on online learning during the Covid-19 lockdown. The third section produced data on the influence of parental support during the student's online sessions. Finally, the fourth section provided data on student's performance.

To obtain data on the independent variable (online learning), which is the 5-point Likert's scale, was adapted from (Darius et al., 2021; Lockman \& Schirmer, 2020; Najafi, 2012). It measured 5 items. Next, to acquire data on the mediating variable (parental support), the questions were adapted from (Cui et al., 2021; Seginer, 2006). The measure contained 5 items. To evaluate the dependent variable (student's performance), the questions were adapted from (Gopal et al., 2021; Bayrak et al., 2020; Shehzadi, 2020). The measure comprised 5 items. The demographic profile contained 5 questions to identify the profile of the respondents involved in this study.

To test the instrument's reliability used to gather the data for this study, Cronbach's Alpha was examined. The $\alpha$ values were all above 0.8 , which indicated that the instrument's internal consistency was good. Table 1 shows the reliability of the instrument used in this research.

Table 1: Reliability Analysis

\begin{tabular}{|l|c|c|}
\hline Variables & Cronbach's Alpha & No of Items \\
\hline Online Learning (ONL) & 0.874 & 5 \\
\hline Parent's Support (PRS) & 0.910 & 5 \\
\hline Student's Performance (STP) & 0.891 & 5 \\
\hline
\end{tabular}




\subsection{Population, Sampling and Measurements}

The population of this study is Malaysian citizens living in the rural areas in Peninsula Malaysia. The Malaysian population is approximately 32.7 million in 2020 (DOSM, 2020). The total population in the rural areas of Malaysia is approximately 22.8 percent of the total population which is approximately 7.4 million (The World Bank, 2020). The (Krejcie and Morgan, 1970) population and sample size tabulation was utilised to obtain an appropriate sample size for this study from the population. Based on (Krejcie and Morgan, 1970) tabulation, the $\alpha$ value is 0.05 , and the degree of accuracy is 0.05 . Thus, no computations were required when establishing the sample size for this research. As the population of Malaysian citizens in the rural areas is 7.4 million (DOSM, 2020), according to (Krejcie and Morgan, 1970) formulation, the adequate sample size is 346 . Therefore, a sample size of 650 was regarded as a fit for this study by the researcher.

A simple random sampling technique was used in this study. The respondents willingly participated in the survey without any persuasion. A total of 650 questionnaires were distributed to families living in the rural areas in the states of Selangor, Perak, and Pahang in Peninsular Malaysia. A total of 437 questionnaires were received, which is approximately a 67.2 percent return rate. While collation, it was released that 11 out of 437 questionnaires that were returned were not fully completed. Therefore, a total of 426 questionnaires provided the data for this research.

Factor Analysis was conducted, which explains the construction of associations within the group of variables. SPSS version 26 was used to analyse the descriptive statistics and correlation analysis, which provided the association between variables. A series of regression analyses using Jamovi (Version 2.0) (The Jamovi Project, 2021) was used to test the mediation effects, path estimates, and hypothesis.

\section{Findings and Interpretation}

The following section provides the findings of this study, which includes the demographic profiles of the respondents, factor analysis, descriptive analysis, correlation and regression analysis.

\subsection{Demographic Profile of Parents}

The profile of the respondents studied is displayed in Table 2.

The demographic profile of the parents surveyed in this research is shown in Table 2. The survey exhibits that the majority of the parents were females (66.7\%). Age wise, the majority were between $(35-40)$ years old $(37.3 \%)$. A majority of $(34.7 \%)$ parents in this study work as clerical staff. In terms of academic qualification, the majority of the parents have completed secondary education $(74.2 \%)$. A majority of $(63.8 \%)$ of the parents belong to the Malay ethnic group. In terms of the number of children, the majority of parents have between $2-4$ children at schooling age (64.3\%). Finally, in terms of the children's academic level, the majority were studying at the higher primary (year 4 -year 6) level or $(28.6 \%)$. 


\begin{tabular}{|c|c|c|c|}
\hline \multicolumn{4}{|c|}{ Table 2: Demographic Profile $(\mathrm{N}=426)$} \\
\hline Demographics & Category & Frequency & Percentage \\
\hline \multirow[t]{2}{*}{ Gender } & Male & 142 & 33.3 \\
\hline & Female & 284 & 66.7 \\
\hline \multirow[t]{4}{*}{ Age } & $25-30$ & 107 & 25.2 \\
\hline & $35-40$ & 159 & 37.3 \\
\hline & $45-50$ & 87 & 20.4 \\
\hline & $55-60$ & 73 & 17.1 \\
\hline \multirow[t]{5}{*}{ Occupation Level } & Unemployed & 87 & 20.4 \\
\hline & Self-employed & 111 & 26.1 \\
\hline & Clerical & 148 & 34.7 \\
\hline & Supervisory & 59 & 13.8 \\
\hline & Managerial & 21 & 5.00 \\
\hline \multirow[t]{5}{*}{ Academic Qualification } & Primary & 7 & 1.60 \\
\hline & Secondary & 316 & 74.2 \\
\hline & Diploma & 79 & 18.6 \\
\hline & Undergraduate & 24 & 5.60 \\
\hline & Post-Graduate & 0 & 0 \\
\hline \multirow[t]{4}{*}{ Ethnicity } & Malay & 272 & 63.8 \\
\hline & Chinese & 58 & 13.6 \\
\hline & Indian & 66 & 15.5 \\
\hline & Others & 30 & 7.10 \\
\hline \multirow[t]{3}{*}{ No of Children } & 1 & 65 & 15.3 \\
\hline & $2-4$ & 274 & 64.3 \\
\hline & More than 4 & 87 & 20.4 \\
\hline \multirow[t]{4}{*}{ Children's Academic Level } & Lower Primary (Yr 1 - Yr 3) & 103 & 24.2 \\
\hline & Higher Primary (Yr 4 - Yr 6) & 122 & 28.6 \\
\hline & Lower Secondary (Fr 1 - Fr 3) & 116 & 27.2 \\
\hline & Higher Secondary (Fr $4-\operatorname{Fr} 5)$ & 85 & 20.0 \\
\hline
\end{tabular}

\subsection{Factor Analysis}

Table 3 Factor Analysis shows the principal variables that explain the framework of associations within the group of variables. Table 3 displays the factors, the items and factor loading of each item used in this study. Four factor loadings were greater than 0.8 . Six factors loaded between 0.7 and 0.8 and five factors loaded between 0.6 and 0.7 . Therefore, it can be deduced that the factor loadings were adequate in this research.

Table 3: Factor Analysis

\begin{tabular}{|l|l|c|}
\hline Factor ID & Factors \& Items & $\begin{array}{c}\text { Factor } \\
\text { Loading }\end{array}$ \\
\hline & Online Learning (ONL) & 0.768 \\
\hline ONL1 & My children can easily access the online learning platform. & 0.695 \\
\hline ONL2 & $\begin{array}{l}\text { My children were able to actively communicate with their teachers and } \\
\text { classmates. }\end{array}$ & 0.775 \\
\hline ONL3 & My children always show enthusiasm in their online sessions. & 0.814 \\
\hline ONL4 & $\begin{array}{l}\text { My children are motivated by the study materials provided in their } \\
\text { online platform. }\end{array}$ \\
\hline
\end{tabular}




\begin{tabular}{|l|l|c|}
\hline \hline ONL5 & $\begin{array}{l}\text { My children find it easy to collaborate with their classmates to complete } \\
\text { their online class activities. }\end{array}$ & 0.649 \\
\hline & Parent's Support & 0.861 \\
\hline PRS1 & $\begin{array}{l}\text { I help my children to setup or access the online platform whenever a } \\
\text { problem occurs. }\end{array}$ & 0.792 \\
\hline PRS2 & $\begin{array}{l}\text { I read reading assignments posted in the online portal and explain it to } \\
\text { my children. }\end{array}$ & 0.693 \\
\hline PRS3 & I always help my children with their online homework. & 0.877 \\
\hline PRS4 & $\begin{array}{l}\text { I often help my children plan and supervise their online learning sessions } \\
\text { and study time }\end{array}$ & 0.715 \\
\hline PRS5 & I have setup a conducive online learning environment for my children \\
\hline & Student's Academic Performance & 0.688 \\
\hline STP1 & The online sessions have enhanced my children's written skills. & 0.852 \\
\hline STP2 & The online sessions have perfected my children's problem-solving skills. & 0.766 \\
\hline STP3 & $\begin{array}{l}\text { The online learning sessions have heightened my children's } \\
\text { understanding in all the subjects. }\end{array}$ & 0.640 \\
\hline STP4 & $\begin{array}{l}\text { The online learning sessions have heightened my children's reading } \\
\text { skills. }\end{array}$ & 0.736 \\
\hline STP5 & My children have obtained good results in their online examinations. \\
\hline
\end{tabular}

\subsection{Mean, Standard Deviation and Normality Analysis}

The descriptive statistics in Table 4 shows the mean, standard deviation (SD), skewness and kurtosis values of this study.

Table 4: Descriptive Statistics

\begin{tabular}{|l|c|c|c|c|c|c|}
\hline Factors & Mean & SD & Skew & Kurtosis & Min & Max \\
\hline Online Learning (ONL) & 4.411 & 0.446 & 0.276 & 1.582 & 3.6 & 5.0 \\
\hline Parent's Support (PRS) & 4.332 & 0.506 & 0.277 & 1.290 & 3.4 & 5.0 \\
\hline Student's Performance (STP) & 4.345 & 0.533 & 0.084 & 1.371 & 3.2 & 5.0 \\
\hline
\end{tabular}

From Table 4, the online learning indicates the highest mean value of $4.411 \pm 0.446$. The lowest mean value is parent's support, $4.332 \pm 0.506$. The normality test shows that the skewness and kurtosis values have a threshold of \pm 2 which means that the data are distributed normal as elucidated by (Chinna \& Yuen, 2015; Gravetter \& Wallnau, 2014).

\subsection{Correlation Analysis}

To study how the variables are correlated, the correlation analysis is shown in Table 5: Correlation Matrix.

Table 5: Correlation Matrix

\begin{tabular}{|l|c|c|c|}
\hline Factors & ONL & PRS & STP \\
\hline Online Learning (ONL) & 1 & & \\
\hline Parent's Support (PRS) & $0.721^{* *}$ & 1 & \\
\hline Student's Performance (STP) & $0.672^{* *}$ & $0.797^{* *}$ & 1 \\
\hline
\end{tabular}

** Correlation is significant at the 0.01 level (2-tailed) 
Based on the correlation matrix shown in Table 5, it was noted that the data significantly backed the measurement model. The correlation matrix recorded that the item online learning strongly correlated with the item Parent's support $(\mathrm{r}=0.721 ; \mathrm{p}<0.001)$ and moderately correlated with student's performance $(\mathrm{r}=0.672 ; \mathrm{p}<0.001)$. The item parent's support strongly correlated with the item student's performance $(r=0.797 ; p<0.001)$.

Therefore, it can be concluded that there is a positive association between the variable online learning and both the variables parent's support and student's performance. Additionally, there is also a positive association between parent's support and student's performance.

\subsection{Mediation Analysis}

To conduct the mediation analysis a series of regression analysis was conducted using Jamovi (Version 2.0) (The Jamovi Project, 2021).

Table 6: Mediation Estimates

\begin{tabular}{|l|c|c|c|c|c|c|c|}
\hline Effect & Estimate & SE & $\mathbf{Z}$ & $\mathbf{p}$ & \% Mediation & LLCI & ULCI \\
\hline Indirect & 0.561 & 0.0440 & 12.77 & $<.001$ & 70 & 0.474 & 0.653 \\
\hline Direct & 0.241 & 0.0490 & 4.92 & $<.001$ & 30 & 0.145 & 0.338 \\
\hline Total & 0.802 & 0.0429 & 18.71 & $<.001$ & 100 & 0.718 & 0.887 \\
\hline
\end{tabular}

Table 7: Path Estimates

\begin{tabular}{|l|l|l|c|c|c|c|}
\hline & Path & & Estimate & SE & Z & p \\
\hline ONL & (a)------> & PRS & 0.817 & 0.0381 & 21.46 & $<.001$ \\
\hline PRS & (b)-----> & STP & 0.687 & 0.0432 & 15.89 & $<.001$ \\
\hline ONL & $\left(c^{\prime}\right)----->$ & STP & 0.241 & 0.0490 & 4.92 & $<.001$ \\
\hline
\end{tabular}

Based on Table 6: Mediation Estimates, the result shows that online learning positively predicts student's academic performance $(B=0.802, \mathrm{Z}=18.71, \mathrm{p}<0.001)$. Analysing the indirect effects, the results reveal that parent's support significantly mediates the relationship between online learning and student's academic performance $\left(a^{*} b=0.561\right.$, $\mathrm{Z}=12.77, \mathrm{p}<0.001,95 \% \mathrm{CI}, 0.474$ to 0.653 ). Additionally, the bootstrap lower level confidence interval (LLCI=0.474) and the upper-level confidence interval (ULCI=0.653) are positive. The value zero is not contained between the LLCI and ULCI, which indicates that the variable parent's support is a statistically significant mediator between the relationship online learning and student's academic performance. Therefore, it can be deduced that the statistical data supported hypothesis $\mathrm{H}_{4}$.

Based on Table 7: Path Estimates for (path a) shown in Figure 1: Proposed Conceptual Model, online learning positively affects parent's support $(B=0.817, Z=21.46$, $\mathrm{p}<0.001$ ). Therefore, hypothesis $\mathrm{H}_{1}$ is supported by statistical data. Path estimate for (path b) shown in Figure 1: Proposed Conceptual Model, parent's support, in turn, positively affects student's academic performance $(B=0.687, Z=15.89, \quad \mathrm{p}<0.001)$. Therefore, hypothesis $\mathrm{H}_{2}$ is supported by statistical data. 
Nevertheless, the results also suggest that even after accounting for the mediating role of parent's support, online learning still has a positive impact on the student's academic performance which is path $c^{\prime}$ as shown in Figure 1: Proposed Conceptual Model $(B=0.241, Z=4.92, p<0.001)$. Additionally, the mediating effect of parent's support accounts for $70 \%$ of the total effect between online learning and the student's academic performance as displayed in Table 6: Mediation Estimates. Therefore, hypothesis $\mathrm{H}_{3}$ is also supported by statistical data.

Thus, it can be concluded that parent's support statistically and significantly mediates the relationship between online learning and student's academic performance in the rural areas in Malaysia.

\section{Discussion}

This study emphasised the mediating effect of parent's support between online learning and students' academic performance in Malaysia's rural areas during the Covid-19 pandemic lockdown. A total of 426 responses from parents generated the data for this study.

The first objective of this study was to examine the significant relationship between online learning and parent's support in rural areas in Malaysia. The result revealed that hypothesis $\mathrm{H} 1$ is supported by data and subsequently disclosed a statistically significant relationship between online learning and parent's support for their children during the Covid-19 pandemic lockdown in the rural area in Malaysia. This outcome is parallel to the findings of (Ribeiro et al., 2021; Tran et al., 2020; Boonk et al., 2018), who revealed that parent's assistance and encouragement were essential to ensure student's performance is maintained. Moreover, research has indicated that young learners may not be able to use the online platforms (Daniela, 2021; Abuhammad, 2020; Dong et al., 2020; Bhamani et al., 2020; Garbe et al., 2020). Therefore, parent's constant observation and support are vital to ensure that their children's learning process takes place without any tribulations. Additionally, the findings of this study were reinforced by scholars (Amber et al., 2020; Bozkurt, 2020) who found that parents need to inspire and guide the student during the online learning sessions so that students get the most out of the online learning mode.

Contrarily, a study conducted by (Yi \& Lee, 2021) uncovered that the parents were not well versed with the online platforms and were not ready to accept online learning as a good learning approach. Though there exist contradicting findings, this research was able to close the gap and invalidate the findings of (Yi \& Lee, 2021).

Therefore, previous discoveries and this research has proven that parent's support is highly significant for their children during their online learning sessions. The support rendered by the parents will enable the students to engage in online learning more enthusiastically.

The second objective of this study was to scrutinise if there is a significant relationship between parent's support and student's academic performance. The result 
disclosed that hypothesis $\mathrm{H} 2$ is supported by data and successively unveiled a statistically significant relationship between parent's support and their children's academic performance. This is in line with the findings of previous researchers (Lara \& Saracostti, 2019; Amponsah et al., 2018; Masa, 2017; Otani, 2017;)who elucidated that parent support in student's learning process is significantly associated with improved academic performance. Additionally, researchers (Sheldon, 2009; Richardson, 2009; Sanders, 2009) have found that when parents are involved and support their children in their learning process, it leads to a more favourable academic performance and creates a strong bond between parent and child.

Conversely, (Yi \& Lee, 2021; Dong et al., 2020) found that parents were having some difficulties supporting their children, which decreased their academic performance. However, this research and previous studies have nullified the findings of (Yi \& Lee, 2021; Dong et al., 2020). Though there exist contradicting findings, this research was able to close the gap in the literature, indicating that the more the parents supported their children, the more positive the outcome of the children's academic performance.

The third objective of this study was to study if there is a significant relationship between online learning and student's academic performance. Consequently, exposing that hypothesis $\mathrm{H} 3$ is supported by data and a statistically significant relationship between online learning and students' academic performance in the rural areas during the Covid-19 pandemic lockdown period. The outcome of this study result can be corroborated by previous scholars (Gopal et al., 2021; Loton et al., 2020; Fatoni et al., 2020; Zameni et al., 2011; Pei \& Wu, 2019; Means et al., 2010), who discovered that that student who used online learning mode performed reasonably better than students who learned through the conventional classroom method. To further support the findings of this research (Darius et al., 2021; Lockman \& Schirmer, 2020; Mahdinejad \& Amoii, 2011) has asserted that online learning has heightened student's academic performance through the use of various online platforms and has exposed students to a new way of interacting with their teachers and this has stimulated interest and motivated students to gain knowledge which led to amplified academic performance.

On the contrary, (Yi \& Lee, 2021) revealed that most students could not complete their homework independently and lost their interest in online learning, which resulted in poor academic performance. Though there exist opposing findings, this research was able to close the gap in the literature, signifying that through online learning sessions, the students in the rural areas in Malaysia were still able to reach a significant increase in their academic performance during the Covid-19 pandemic lockdown.

The fourth objective of this study was to analyse if parent's support mediates the relationship between online learning and student's academic performance. The results established that hypothesis $\mathrm{H} 4$ is supported by data, subsequently denoting that parent's support mediates the relationship between online learning and student's academic performance. This outcome substantiates and parallels previous researchers (Lorenzo et al., 2017; Sooter, 2013; Seginer, 2006; Bradley \& Corwyn, 2002) affirmed that parent's 
support during online learning at home strengthens the parent-children relationship, which then helps to elevate the children's academic performance.

In contrast, (Cui et al., 2021) implied that online learning caused stress on the parents and reduced the students' academic performance. Therefore, a gap exists regarding the intervening role of parents during their children's online sessions during the Covid-19 pandemic lockdown period. However, this research was able to close the gap in the literature, demonstrating that through the parent's continuous support, the student will become more self-reliant in their online learning at home and ultimately attain better academic performance

\section{Conclusion}

This mediation study was performed to determine if parent's support mediates the relationship between online learning at home and students' academic performance during the Covid-19 lockdown in rural areas in Malaysia. The results verified that parent's support for their children is highly significant. When the children are learning using the online platforms, parents ' constant encouragement and facilitation are significant for the child to attain better academic results. This can be corroborated by the findings of previous researchers (Ribeiro et al., 2021; Daniela, 2021; Gopal et al., 2021; Tran et al., 2020; Abuhammad, 2020; Dong et al., 2020; Bhamani et al., 2020; Garbe et al., 2020; Loton et al., 2020; Fatoni et al., 2020).

Some previous researchers (Yi \& Lee, 2021; Cui et al., 2021; Dong et al., 2020) have implied that parents were going through some difficulties and stress when supporting their children's online learning sessions, which decreased the children's academic performance. However, this research has proven that parent's support is statistically and significantly vital for their children's online learning, which would enhance their children's academic performance.

Finally, this study's findings and literature can guide academics in public and private education sectors, parents, and the Ministry of Education to focus and upgrade the online learning and teaching facilities rather than just depending on face-to-face teaching and learning. Online learning could be beneficial whenever a catastrophic incident takes place, which may disrupt children's education. As such, it would be wise to encourage parents to be always ready for this new way of learning in the new milieu.

\subsection{Limitations and Further Research}

The focus of this study was only on the students' academic in some rural areas in the states of Selangor, Perak, and Pahang in Peninsular Malaysia. Consequently, to acquire more knowledge on this mediation study, research can be conducted on a much bigger scale encompassing other states in Malaysia. A study could also be undertaken to compare the support of parents in urban and rural areas in Malaysia. 


\section{Acknowledgements}

The authors would like to express their sincere gratitude to all the parents for allowing the authors to conduct this research and value the time they have spent answering the questionnaire.

\section{Conflict of Interests Statement}

The authors of this research would like to declare that there are no conflicts of interest linked with this research, and this research was not sponsored by anyone that could have influenced its outcomes. As the researchers of this study, the authors validate its novelty and assert that this study has not been published previously and verify that it is not presently being considered for publication elsewhere.

\section{About the Authors}

The authors are academicians and researchers who have been involved in scholarly and research activities for over two decades.

\section{References}

Abuhammad, S. (2020). Barriers To Distance Learning During the Covid-19 Outbreak: A Qualitative Review from Parents' Perspective. Heliyon 2020, 6, 1-5.

Ahn, J., Butler, B. S., Alam, A., \& Webster, S. A. (2013). Learner Participation and Engagement in Open Online Courses: Insights from The Peer 2 Peer University. Merlot Journal of Online Learning and Teaching, 9(2), 160-171. Retrieved From: https://jolt.merlot.org/vol9no2/ahn 0613.pdf

Amber, G., Ogurlu, U., Logan, N., \& Cook, P. (2020). Parents' Experiences with Remote Education During Covid-19 School Closures. Am. J. Qual. Res, 4, 45-65.

Amponsah, M. W., Milledzi, E. Y., \& Ampofo, E. T. (2018). Relationship Between Parental Involvement and Academic Performance of Senior High School Students: The Case of Ashanti Mampong Municipality of Ghana. American Journal of Educational Research, 6(1), 1-8.

Antipkina, I., \& Ludlow, L. H. (2020). Parental Involvement as A Holistic Concept Using Rasch/Guttman Scenario Scales. J. Psychoeduc. Assess, 38, 846-865

Bayrak, D. F., Moanes, D. M., \& Altun, D. A. (2020). Development Of Online Course Satisfaction Scale. Turkish Online Journal of Distance Education, 21(4), 110-122. https://doi.org/10.17718/tojde.803378.

Bhamani, S., Makhdoom, A. Z., Bharuchi, V., Ali, N., Kaleem, S., \& Ahmed, D. (2020). Home Learning in Times of Covid: Experiences of Parents. Journal Of Education and Educational Development, 7(1), 9-26.

Boonk, L., Gijselaers, H., Ritzen, H., \& Brand-Gruwel, S. (2018). A Review of The Relationship Between Parental Involvement Indicators and Academic Achievement. Educational Research Review, 24. 
Bowen, N. K. (1999). A Role for School Social Workers in Promoting Student Success Through School - Family Partnerships. Social Work in Education, 21(1), 34-48.

Bowen, W. G. (2013). Higher Education in The Digital Age. Princeton University Press. Bozkurt, A., Jung, I., Xiao, J., Vladimirschi, V., Schuwer, R., Egorov, G., Lambert, S. R., Al-Freih, M., Pete, J., \& Olcott, D., Jr. (2020). A Global Outlook to The Interruption of Education Due to Covid-19 Pandemic: Navigating in A Time of Uncertainty and Crisis. Asian Journal of Distance Education, 15, 1-126.

Bradley, R. H., \& Corwyn, R. F. (2002). Introduction To Socioeconomic Status and Child Development. Annual Review of Psychology, 53, 371-399.

Bruni, O., Sette, S., Fontanesi, L., Baiocco, R., Laghi, F., \& Baumgartner, E. (2015). Technology Use and Sleep Quality in Preadolescence and Adolescence. Journal of Clinical Sleep Medicine, 11(12), 1433-1441. https://doi.org/10.5664/jcsm. 5282.

Byeon, H., \& Hong, S. (2015). Relationship Between Television Viewing and Language Delay in Toddlers: Evidence from A Korea National Cross-Sectional Survey. Plos One, 10(3), E0120663. https://doi.org/10.1371/journal.pone. 0120663

Cai, J. (2003). Investigating Parental Roles in Students' Learning of Mathematics from A Cross-National Perspective. Mathematics Education Research Journal, 15(2), 87- 106. Chang, G. C., \& Yano, S. (2020). How Are Countries Addressing the Covid-19 Challenges in Education? A Snapshot of Policy Measures. Retrieved From World Education Blog: https://gemreportunesco.wordpress.com.

Cheesman, J., Simpson, N., \& Wint, A. (2006). Determinants Of Student Performance at University: Reflections from The Caribbean. Retrieved From: http://www.mona.uwi.edu/opair/research/student-performance-paperrevised.pdf

Chinna, K. \& Yuen, C. W. (2015). Statistical Analysis Using SPSS. (2 ${ }^{\text {nd }}$ Ed.). Pearson Malaysia.

Cui, S., Zhang, C., Wang, S., Zhang, X., Wang, L., Zhang, L., Yuan, Q., Huang, C., Cheng, F., Zhang, K., \& Zhou, X. (2021). Experiences And Attitudes of Elementary School Students and Their Parents Toward Online Learning in China During the Covid19 Pandemic: Questionnaire Study, Journal of Medical Internet Research, 23(5).

Daniela, L., Rubene, Z., \& Rudolfa, A. (2021). Parents' Perspectives on Remote Learning in The Pandemic Context. Sustainability 2021, 13, 3640.

Darius, P. S. H., Gundabattini, E., \& Darius, G. S. (2021). A Survey on The Effectiveness of Online Teaching-Learning Methods for University and College Students. Journal of the Institution of Engineers (India): Series B. 1-10.

Department of Statistics Malaysia Dosm. (2020). Current Population Estimates, Malaysia, 2020. Retrieved From: http://www.dosm.gov.my.

Desforges, C. \& Abouchaar, A. (2003). The Impact of Parental Involvement, Parental Support and Family Education on Pupil Achievement and Adjustment: $A$ Literature Review, Department of Education and Skills.

Dong, C., Cao, S., \& Lia, H. (2020). Young Children's Online Learning During Covid-19 Pandemic: Chinese Parents' Beliefs and Attitudes. Child. Youth Serv. Rev, 118, 2-9. 
Dube, B. (2020). Rural Online Learning in The Context of Covid 19 In South Africa: Evoking an Inclusive Education Approach. Multidisciplinary Journal of Educational Research, 10(2), 135-157. doi: 10.4471/remie.2020.5607

Epstein, J. L. (1994). Theory To Practice: School and Family Partnerships Lead to School Improvement and Student Success. In C. L. Fagnano \& B. Z. Werber (Eds.), School, Family, And Community Interaction: A View from The Firing Lines. 39-52. Boulder, Co: Westview.

Epstein, J. L., \& Sander, M. (2000). Handbook of the Sociologic of Education. New York, Ny: Springer.

Evans, M. A., Shaw, D., \& Bell, M. (2000). Home Literacy Activities and Their Influence on Early Literacy Skills. Canadian Journal of Experimental Psychology, 54, 65-75.

Fatoni, A., Nurkhayati, N., Nurdiawati, E., Fidziah, E., Pamungkas, G., \& Azizi, E. (2020). University Students Online Learning System During Covid-19 Pandemic: Advantages, Constraints, And Solutions. Systematic Reviews in Pharmacy, 11(7), 570-576. https://doi.org/10.31838/srp.2020.7.81

Finn, J. D. (1998). Parental Engagement That Makes a Difference. Educational Leadership, 55, 20-24.

Fontanesi, L., Marchetti, D., Mazza, C., Di Giandomenico, S., Roma, P., \& Verrocchio, M.C. (2020). The Effect of The Covid-19 Lockdown on Parents: A Call to Adopt Urgent Measures. Psychol. Trauma Theory Res. Pract. Policy, 12, S79-S81.

Friedel, J., Cortina, K. S., Turner, J. C., \& Midgley, C. (2010). Changes In Efficacy Beliefs in Mathematics Across the Transition to Middle School: Examining the Effects of Perceived Teacher and Parent Goal Emphases. Journal of Educational Psychology, 10, 102-114.

Gálvez, I., Cruz, F. J. F., Díaz, M. J. F., \& Roberts, B. (2016). Evaluation of the Impact of Quality Management Systems on School Climate. International Journal of Educational Management, 30(4), 474-492.

Garbe, A., Ogurlu, U., Logan, N., \& Cook, P. (2020). Covid-19 And Remote Learning: Experiences of Parents with Children During the Pandemic. American Journal of Qualitative. Research, 4, 45-65.

Garbett, C. (2011). Activity-Based Costing Models for Alternative Modes of Delivering On-Line Courses. European Journal of Open, Distance and E-Learning, 1-14.

Gestwicki, C. (1996). What Is Parent Involvement? Home School and Community Relations -A Guide to Working with Parents.(3rd Ed.) 83-106. Delmar Publishers Albany, Ny.

Gopal, R., Singh, V. \& Aggarwal, A. (2021). Impact Of Online Classes on The Satisfaction and Performance of Students During the Pandemic Period of Covid 19. Educ Inf Technol. https://doi.org/10.1007/s10639-021-10523-1

Gould, P. (1999). Parents Are Stepping Out of Their Passive Roles. San Diego Business Journal, 20(18), 6-10.

Gravetter, F. \& Wallnau, L. (2014). Essentials of Statistics for The Behavioural Sciences. (8 $8^{\text {th }}$ Ed.), Belmont, Ca: Wadsworth. 
Green, K. C. (2010). The Campus Computing Survey. The Campus Computing Project. http://www.CampuscomPuting.Net/2010-Campus-Computing-Survey

Gugiu, P. C., Gugiu, M. R., Barnes, M., Gimbert, B., \& Sanders, M. (2019). The Development and Validation of The Parental Involvement Survey in Their Children's Elementary Studies (Pisces). J. Child Fam. Stud, 28, 627-641.

Guolaug, G. (2010). Effects Of Parental Involvement in Education: A Case Study in Namibia. Unpublished PhD Dissertation, Faculty of Education Studies, University of Iceland.

Harris, A. And J. Goodall (2008). Do Parents Know They Matter? Engaging All Parents in Learning. Educational Research 50(3): 277 - 289.

Hayes, A. F. (2018). Introduction To Mediation, Moderation, And Conditional Process Analysis: A Regression-Based Approach, (2nd Ed.). New York, Ny: Guilford Press.

Hoover-Dempsey, K. V., \& Sandler, H. M. (1997). Why Do Parents Become Involved in Their Children's Education? Rev. Educ. Res, 67, 3-42.

Hoover-Dempsey, K. V., Walker, J. M. T., Sandler, H. M., Whetsel, D., Green, C. L., Wilkins, A. S., \& Closson, K. (2005). Why Do Parents Become Involved? Research Findings and Implications. Elem. Sch. J., 106, 105-130

Hurley, K. D., Lambert, M. C., January, S. A., \& D'angelo, J. F. (2017). Confirmatory Factor Analyses Comparing Parental Involvement Frameworks with Secondary Students. Psychol. Sch., 54, 947-964.

Ilag B. N. (2018) Introduction: Microsoft Teams. In: Introducing Microsoft Teams. Apress, Berkeley, Ca. https://doi.org/10.1007/978-1-4842-3567-6 1

Ishak, M. (2021). 47 Children Under 18 Died from Covid-19 Since the Start of Pandemic. The New Straits Times (2 $2^{\text {nd }}$ September 2021).

Jeynes, W. H. (2005). The Effects of Parental Involvement on The Academic Achievement of African American Youth. The Journal of Negro Education, 260-274.

Jeynes, W. H. (2007). The Relationship Between Parental Involvement and Urban Secondary School Student Academic Achievement: A Meta-Analysis. Urban Education, 42(1), 82-110.

Kong, Q. (2020). Practical Exploration of Home Study Guidance for Students During the Covid-19 Pandemic: A Case Study of Hangzhou Liuxia Elementary School in Zhejiang Province, China. Sci. Insigt Edu. Front., 5, 557-561.

Krejcie, R. V., \& Morgan, D. W. (1970). Determining Sample Size for Research Activities. Educational \& Psychological Measurement.

Langevine, J. A. E. (2020). Parental Involvement and Academic Achievement of Middle School: Hispanic American Students in South Texas (Doctoral Dissertation, Grand Canyon University).

Lara, L., \& Saracostti, M. (2019). Effect Of Parental Involvement on Children's Academic Achievement in Chile. Frontiers Psychology,10:1464. doi: 10.3389/fpsyg.2019.01464 Lindsay, G., Davis, H. (2009). Parent Support Advisor Pilot Evaluation Final Report. London, Dcsf. 
Liu, Y., Sulaimani, M. F., \& Henning, J. E. (2020). The Significance of Parental Involvement in The Development in Infancy. Journal of Educational Research and Practice, 10, 161-166.

Lockman, A. S., \& Schirmer, B. R. (2020). Online Instruction in Higher Education: Promising, Research Based, and Evidence-Based Practices. Journal of Education and E-Learning Research, 7(2), 130-152.

Lorenzo, M., Godás, A., \& Santos Rego, M. A. (2017). Main Determinants of Immigrant Families' Involvement and Participation in School Life. Cultura Y Educación, 29(2), 213-253. https://doi.org/10.1080/11356405.2017.1305074

Loton, D., Parker, P., Stein, C., \& Gauci, S. (2020). Remote Learning During Covid-19: Student Satisfaction and Performance. Edarxiv,7(3),1-9 https://www.researchgate.net/publication/342686256 Remote learning during COVID-19 Student satisfaction and performance

Mahdinejad, V. \& Amoii, M. (2011). Assessment Of Computer Self-Efficacy and Attitudes Toward Computers in University Students. Iranian Journal of Higher Education, 16(4), 102-117.

Masa, D In Mila, B. (2017). Parental Involvement as An Important Factor for Successful Education. C.E.P.S Journal, 7(3), 137 - 152.

Mau, W. (1997). Parental Influences on The High School Student's Academic Achievement: A Comparison of Asian Immigrants, Asian Americans, And White Americans. Psychology In the Schools, 34(3), 267-277.

Means, B., Toyama, Y., Murphy, R., Bakia, M., \& Jones, K. (2010, September). Evaluation Of Evidence-Based Practices in Online Learning: A Meta-Analysis and Review of Online Learning Studies. Monograph. Retrieved February 1, 2014, Retrieved From http://www.ed.gov/about/offices/list.

Möhring, K., Naumann, E., Reifenscheid, M., Blom, A. G., Wenz, A., Rettig, T., Lehrer, R., Krieger, U., Juhl, S., \& Friedel, S., (2020). Die Mannheimer Corona-Studie: Schwerpunktbericht Zu Erwerbstätigkeit Und Kinderbetreuung [The Mannheim Corona Report: Focus on Employment and Childcare]. Retrieved From: https://www.uni-mannheim.de/gip/corona-studie/

Najafi, H. (2012). The Pedagogical Principles and Theories of Distance Education. Iranian Journal Curriculum Planning, 9(7), 32-41.

Navarro, P., \& Shoemaker, J. (2000). Performance And Perceptions of Distance Learners in Cyberspace. American Journal of Distance Education, 14(2), 15-35.

Nyarko, K. (2011). Parental School Involvement: The Case of Ghana. Journal Of Emerging Trends in Education Research and Policy Studies, 2(5), 378-381.

Otani, M. (2017). Relationships Between Parental Involvement and Academic. Osipp Discussion Paper Journal, 1-67.

Pei, L., \& Wu, H. (2019). Does Online Learning Work Better Than Offline Learning in Undergraduate Medical Education? A Systematic Review and Meta-Analysis. Medical Education Online, 24(1), 1666538. 
Porumbu, D., \& Necsoi, D. (2013). Relationship Between Parental Involvement/Attitude and Children's School Achievements. Procedia - Social and Behavioral Sciences. 76. 706-710. doi:10.1016/j.sbspro.2013.04.191

Ribeiro, L. M., Cunha, R. S., Silva, M. C. A. E., Carvalho, M., \& Vital, M. L. (2021). Parental Involvement During Pandemic Times: Challenges and Opportunities. Educ. Sci, $11,302$.

Richardson, S. A. (2009). Principal's Perceptions of Parental Involvement in Urban Districts of Ohio. Research In the Schools, 16(1), 1-12.

Riffell, S., \& Sibley, D. (2005). Using Web-Based Instruction to Improve Large Undergraduate Biology Courses: An Evaluation of a Hybrid Course Format. Computers \& Education, 44(3), 217-235.

Sanders, M. G. \& Sheldon, S. B. (2009). Principals Matter: A Guide to School, Family, And Community Partnerships. Corwin: A Sage Company.

Seginer, R. (2006). Parents' Educational Involvement: A Developmental Ecology Perspective. Parenting: Science and Practice, 6, 1-48.

Shehzadi, S., Nisar, Q. A., Hussain, M. S., Basheer, M. F., Hameed, W. U., \& Chaudhry, N. I. (2020). The Role of Digital Learning Toward Students' Satisfaction and University Brand Image at Educational Institutes of Pakistan: A Post-Effect of Covid-19. Asian Education and Development Studies, 10(2), 276-294.

Sheldon, S. B. (2009). In School, Family, And Community Partnerships: Your Handbook for Action (3rd Ed.). USA: Corwin Press.

Simatwa, E. M. W. (2010). Piaget's Theory of Intellectual Development and Its Implication for Instructional Management at Presecondary School Level. Educational Research and Reviews, 5(7), 366-371.

Smith, S. J., Burdette, P. J., Cheatham, G. A., \& Harvey, S. P. (2016). Parental Role and Support for Online Learning of Students with Disabilities: A Paradigm Shift. Journal Of Special Education Leadership, 29(2), 101 -112.

Sooter, T. (2013). Early Childhood Education in Nigeria: Issues and Problems. Journal of Educational and Social Research, 173-179. https://doi.org/10.5901/jesr.2013.v3n5p173

Spera, C. (2005). A Review of The Relationship Among Parenting Practices, Parenting Styles, And Adolescent School Achievement. Educational Psychology Review, 17(2), 125-146.

Sui-Chu, E. H., \& Willms, J. D. (1996). Effects Of Parental Involvement on Eighth-Grade Achievement. The Sociological Quarterly, 69, 126-141.

The Jamovi Project (2021). Jamovi. (Version 2.0) [Computer Software]. Retrieved From https://www.jamovi.org.

The World Bank (2020). Rural Population (\% of Total Population) - Malaysia. Retrieved From: https://data.worldbank.org/indicator.

Tran, T., Hoang, A. D., Nguyen, Y. C., Nguyen, L. C, Ta, N. T., Pham, Q. H., Pham, C. X., Le, Q. A., Dinh, V. H., \& Nguyen, T. T. (2020). Toward Sustainable Learning During School Suspension: Socioeconomic, Occupational Aspirations, And 
Learning Behaviour of Vietnamese Students During Covid-19. Sustainability, 12(10):4195. https://doi.org/10.3390/su12104195

UNESCO (2020). United Nations Educational, Scientific and Cultural Organization. Covid19 Educational Disruption and Response. UNESCO, Paris, France. https://en.unesco.org/themes/education-emergencies/coronavirus-schoolclosures.

Valerie, J. S., Eric, G. H., Jody, S. U., \& Rim, R. (2011). A Review of The Relationship Between Parental Involvement and Secondary School Students' Academic Achievement. Hindawi Publishing Corporation Education Research International. doi:10.1155/2011/915326

Velez, W., \& Jones, T. G. (1997). Effects Of Parent Involvement on The Academic Achievement of Latino Children, Research and Opinion, 11(1). Retrieved From: www.uwm.edu/dept/cuir/4informationresources/rando/11-1.html

Ventayen, R. J .M., Estira, K. L. A., De Guzman, M. J., Cabaluna, C. M., \& Espinosa, N. N. (2018). Usability Evaluation of Google Classroom: Basis for The Adaptation of Gsuite E-Learning Platform. Asia Pac. J. Educ. Arts Sci. 5(1), 47-51.

Wang, G., Zhang, Y., Zhao, J., Zhang, J., \& Jiang, F. (2020). Mitigate The Effects of Home Confinement on Children During the Covid-19 Outbreak. The Lancet, 395, 945-947.

Wang, M. T., \& Sheikh_Khalil, S. (2014). Does Parental Involvement Matter for Student Achievement and Mental Health in High School? Child Development, 85(2), 610-625.

Waters, L. H., Menchaca, M. P., \& Borup, J. (2014). Parental Involvement In K-12 Online and Blended Learning. In Handbook of Research On K-12 Online and Blended Learning, 403-422.

Wilder, S. (2014). Effects Of Parental Involvement on Academic Achievement: A MetaSynthesis. Educ. Rev, 66, 377-397.

World Health Organisation, Who. (2021). Weekly Epidemiological Update. Retrieved From: https://www.who.int/publications/m/item/weekly

Yi, E. H. L., \& Lee, K. (2021) Parents' Views on Young Children's Distance Learning and Screen Time During Covid-19 Class Suspension in Hong Kong, Early Education and Development, 32(6), 863-880, doi: 10.1080/10409289.2020.

Zameni, F. \& Kardan, S. (2011). Impact Of Using ICT On Learning Mathematics. Iranian Journal of Information and Communications Technology in Education Sciences, 1(1), 2338.

Zameni, F., Nasimi, A., Rezayirad, M., \& Ghanbarpoor, M. (2011). The Impact of Multimedia Applications on The Academic Achievement of Students in A Sociology Class. Iranian Journal of Information and Communications Technology in Education Sciences, 2(2). 
Author(s) will retain the copyright of their published articles agreeing that a Creative Commons Attribution 4.0 International License (CC BY 4.0) terms will be applied to their work. Under the terms of this license, no permission is required from the author(s) or publisher for members of the community to copy, distribute, transmit or adapt the article content, providing a proper, prominent and unambiguous attribution to the authors in a manner that makes clear that the materials are being reused under permission of a Creative Commons License. Views, opinions and conclusions expressed in this research article are views, opinions and conclusions of the author(s). Open Access Publishing Group and European Journal of Education Studies shall not be responsible or answerable for any loss, damage or liability caused in relation to/arising out of conflicts of interest, copyright violations and inappropriate or inaccurate use of any kind content related or integrated into the research work. All the published works are meeting the Open Access Publishing requirements and can be freely accessed, shared, modified, distributed and used in educational, commercial and non-commercial purposes under a Creative Commons Attribution 4.0 International License (CC BY 4.0). 